EFFECT OF HOME EXERCISE PROGRAM IN QUALITY OF LIFE IN PATIENTS WITH ANKYLOSING SPONDYLITIS

\author{
Cristina Mesquita; Sofia Lopes; Maria Excelsa Moreira; Patrícia Lopes; Ana Carneiro; \\ Daniela Silva; Inês Neves; Filipa Araújo; Alice Vitorino; School of Allied Health Sciences of \\ the Polytechnic Institute of Porto, Portugal (ESTSP-IPP)
}

Background and Objectives Ankylosing spondylitis is a chronic, rheumatic and inflammatory disease with a generally progressive course. The pain and stiffness are the main symptoms that cause the individual less mobility and changes in the sleep cycle producing fatigue, anxiety, stress and depression. This group of symptoms changes the well-being and quality of life of individuals. It is important to follow the recommendations of the physiotherapist about duration and frequency to ensure their effectiveness and improve the quality of life of individuals. The objective of this study is to evaluate the effectiveness of a home-based exercise program in quality of life of people with ankylosing spondylitis.

Material and Methods This is a randomised controlled trial. 24 elements had the inclusion criteria and were randomised into control and experimental group. The experimental group performed a home-based exercise program for 5 days a week during 30 minutes each one for 10 weeks, which included straight postural, muscle strength, stretching and respiratory exercises. The evaluation of the individuals performed at baseline and after 10 weeks to carry out the home-based exercise program, follow through WHOQOL-Bref to evaluate the quality of life of individuals, BASDAI, BASFI and BASMI.

Results The experimental group after the program improved the levels of WHOQOL-Bref $(\mathrm{p}=0.027$ for domain $1, p=0.008$ for domain 2 and $\mathrm{p}=0.020$ for domain 4$)$, BASDAI $(\mathrm{p}=0.044)$, BASFI $(\mathrm{p}=0.049)$ and BASMI ( $\mathrm{p}=0.002)$. No statistically significant difference was found in initial time and the end of the study of all scales in control group. Also, there were correlations between all ranges and areas of WHOQOL-Bref, except between BASFI and BASDAI $(r=0)$. The most relevant correlations are between BASFI and domain $3(r=-0.643$; $\mathrm{p}=0.024)$, domain 1 and domain $2(\mathrm{r}=0.712 ; \mathrm{p}=0.009$, domain 1 and domain $4(\mathrm{r}=0.642 ; \mathrm{p}=0.025)$ domain 2 and domain $3(\mathrm{r}=0.711 ; \mathrm{p}=0.010)$, domain 2 and domain $4(\mathrm{r}=0.665 ; \mathrm{p}=0.018)$, domain 3 and domain $4(\mathrm{r}=0.779 ; \mathrm{p}=0.003)$, well as represent meaning for the population.

Conclusion The home-based exercise program is an effective therapy in increasing quality of life of patients with ankylosing spondylitis. Psychological distress and fatigue was improved through better well being and quality of life. 


\section{A RD A2.8 Effect of home exercise program in quality of life in patients with ankylosing spondylitis}

Cristina Mesquita, Sofia Lopes, Maria Excelsa Moreira, Patrícia Lopes, Ana Carneiro, Daniela Silva, Inês Neves, Filipa Araújo and Alice Vitorino

Ann Rheum Dis 2014 73: A41

doi: 10.1136/annrheumdis-2013-205124.93

Updated information and services can be found at:

http://ard.bmj.com/content/73/Suppl_1/A41.1

These include:

Email alerting Receive free email alerts when new articles cite this article. Sign up in the box at the top service right corner of the online article.

$\begin{array}{cc}\text { Topic } & \text { Articles on similar topics can be found in the following collections } \\ \text { Collections } & \text { Ankylosing spondylitis (376) } \\ & \text { Calcium and bone (657) } \\ & \text { Connective tissue disease (3861) } \\ & \text { Degenerative joint disease (4200) } \\ & \text { Immunology (including allergy) (4626) } \\ & \text { Musculoskeletal syndromes (4489) } \\ & \text { Rheumatoid arthritis (2948) } \\ & \text { Epidemiology (1249) } \\ & \text { Pain (neurology) (803) }\end{array}$

\section{Notes}

To request permissions go to:

http://group.bmj.com/group/rights-licensing/permissions

To order reprints go to:

http://journals.bmj.com/cgi/reprintform

To subscribe to BMJ go to:

http://group.bmj.com/subscribe/ 